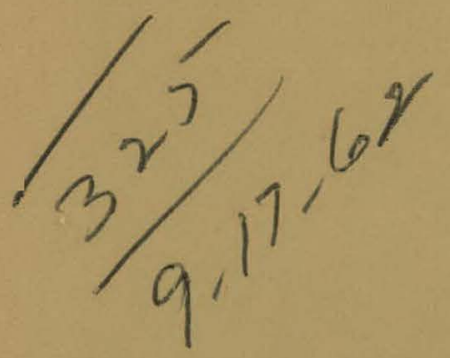

MASTER

DP -760

Instruments

AEC Research and Development Report

GAUGE FOR MEASURING BOW OF TUBES

by

G. B. Alewine

Laboratory Services Division

August 1962

E. I. du Pont de Nemours \& Co.

Savannah River Laboratory

Aiken, South Carolina 


\section{DISCLAIMER}

This report was prepared as an account of work sponsored by an agency of the United States Government. Neither the United States Government nor any agency Thereof, nor any of their employees, makes any warranty, express or implied, or assumes any legal liability or responsibility for the accuracy, completeness, or usefulness of any information, apparatus, product, or process disclosed, or represents that its use would not infringe privately owned rights. Reference herein to any specific commercial product, process, or service by trade name, trademark, manufacturer, or otherwise does not necessarily constitute or imply its endorsement, recommendation, or favoring by the United States Government or any agency thereof. The views and opinions of authors expressed herein do not necessarily state or reflect those of the United States Government or any agency thereof. 


\section{DISCLAIMER}

Portions of this document may be illegible in electronic image products. Images are produced from the best available original document. 
This report was prepared as an account of Government sponsored work. Neither the United States, nor the Commission, nor any person acting on behalf of the Commission:

A. Makes any warranty or representation, expressed or implied, with respect to the accuracy, completeness, or usefulness of the information contained in this report, or that the use of any information, apparatus, method, or process disclosed in this report may not infringe privately owned rights; or

B. Assumes any liabilities with respect to the use of, or for damages resulting from the use of any information, apparatus, method, or process disclosed in this report.

As used in the above, "person acting on behalf of the Commission" includes any employee or contractor of the Commission, or employee of such contractor, to the extent that such employee or contractor of the Commission, or employee of such contractor prepares, disseminates, or provides access to, any information pursuant to his employment or contract with the Commission, or his employment with such contractor.

Printed in USA. Price $\$ 0.50$ Ava1lable from the office of Technical Services

U. S. Department of Commerce

Washington 25, D. C. 
INSTRUMENTS

(TID-4500, 17th Ed.)

\title{
GAUGE FOR MEASURING BOW OF TUBES
}

\author{
by \\ Gretchen B. Alewine
}

August 1962

\author{
E. I. du Pont de Nemours \& Co. \\ Explosives Department - Atomic Energy Division \\ Tcohnical Divisinn - Savannah River Laboratory \\ Aiken, South Carolina \\ Contract $\operatorname{AT}(07-2)-1$ with the \\ United States Atomic Energy Commission
}

Approved by

D. E. Waters, Research Manager Laboratory Services Division 


\begin{abstract}
A mechanical gauge was designed to measure the bow over any one-foot length of long cylindrical material. The gauge has been used successfully for measuring bow in components of tubular fuel elements at the Savannah River Laboratory.
\end{abstract}




\section{CONTENTS}

$\underline{\text { Page }}$

Introduction

Summary

4

Discussion

4

General

4

Design Description

Operation

7

Operating Experience

7

Acknowledgement

\section{LIST OF FIGURES}

\section{Figure}

1 Bow Gauge 5

2 Measuring Positions for Elements of Different Diameters 5

3 Bow Gaugc with Tube in Measuring Position 6 


\section{GAUGE FOR MEASURING BOW OF TUBES}

\section{INTRODUCTION}

A device was needed to measure the short-range bow (bow over any one-foot length) in tubular components of nuclear fuel elements, to determine if they are acceptable for reactor use. Bow measurements, accurate to within \pm 0.001 inch, were required in ribbed and smooth tubes up to 16 feet long with diameters from $1 \frac{1}{2}$ to $3 \frac{1}{2}$ inches. The device needed to be direct reading, portable, easy to operate, and rugged enough to withstand use as a quality control instrument for production use. No known commercial equipment was available that would meet the requirements for this design.

\section{SUMMARY}

A simple gauge was designed to measure the bow in components of various diameters and lengths; it has been used successfully with experimental fuel elements at the Savannah River Laboratory. The gauge has adjustable roller supports for the tubes and a dial indicator for measuring the bow.

\section{DISCUSSION}

\section{GENERAL}

The bow gauge consists basically of a dial indicator located between two tube support assemblies. A tube to be measured is placed on the support assemblies and against two reference points (Figure l). The difference or deviation from a straight line between the two reference points is read on the dial indicator. These measurements were normally read at one-foot intervals along the tube.

\section{DESIGN DESCRIPTION}

The essential components of the bow gauge shown in Figure 1 are roller support assemblies, reference position rollers, and a dial indicator. All the components are adjustable to accommodate a wide range of tube diameters.

Two tube roller support assemblies are spaced 12 inches apart and are mounted to a heavy base plate. The roller assemblies consist of a pair of canted wheels coated with polyethylene, upon which the tubes are supported. The wheels permit easy traversing of the tube through the one-foot gauging steps. One canted wheel on the assembly is attached to a fixed block, the other to an adjustable slide that can be locked in position with slide locks (Figure 1). The adjustable slide is moved close to the fixed block for smaller tubes and away from the block for larger tubes. This movement keeps the centerlines of all tubes within an approximately $\frac{1}{2}$-inch vertical range (Figure 2 ). 


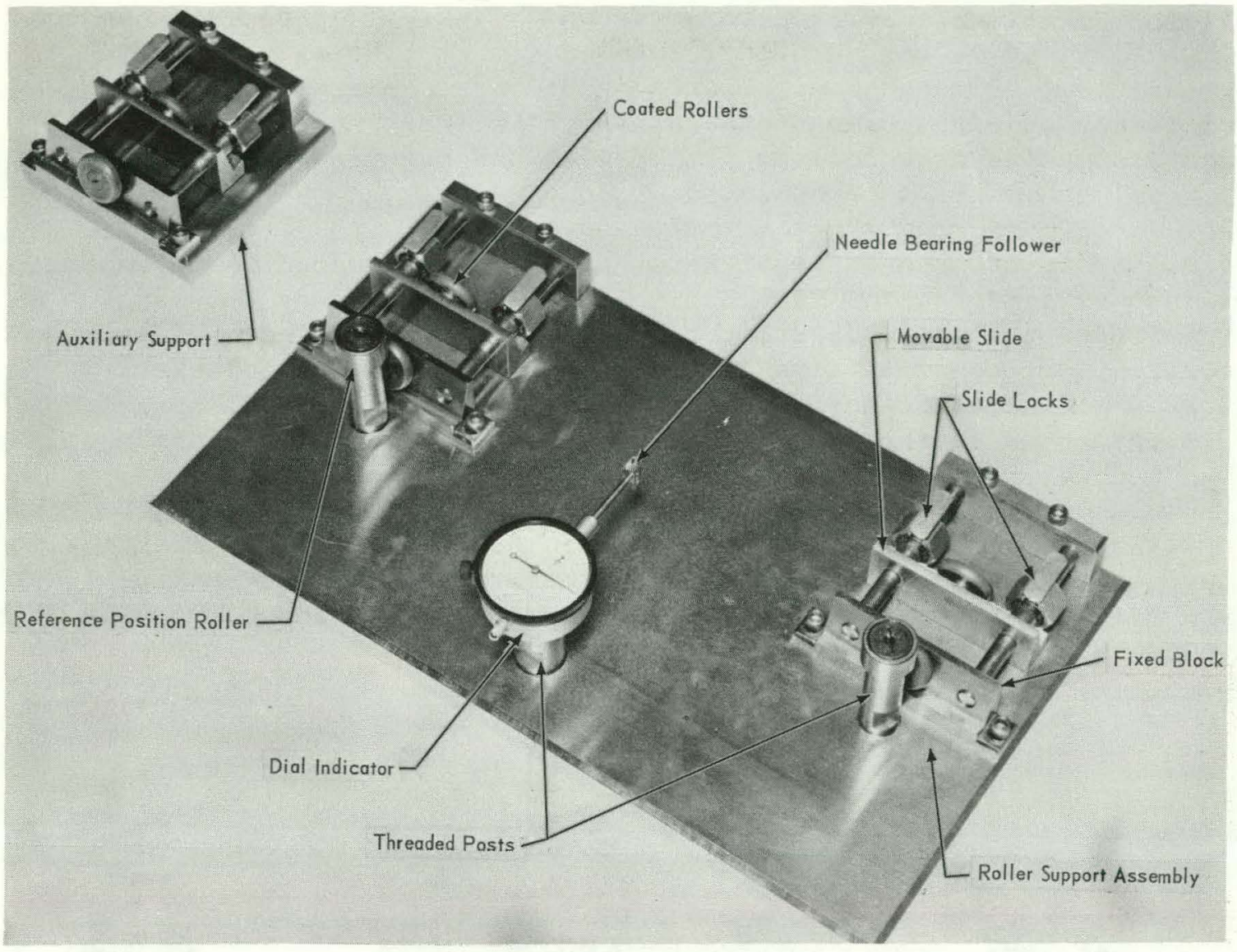

DPST F - 1- 5838

FIG. 1 BOW GAUGE
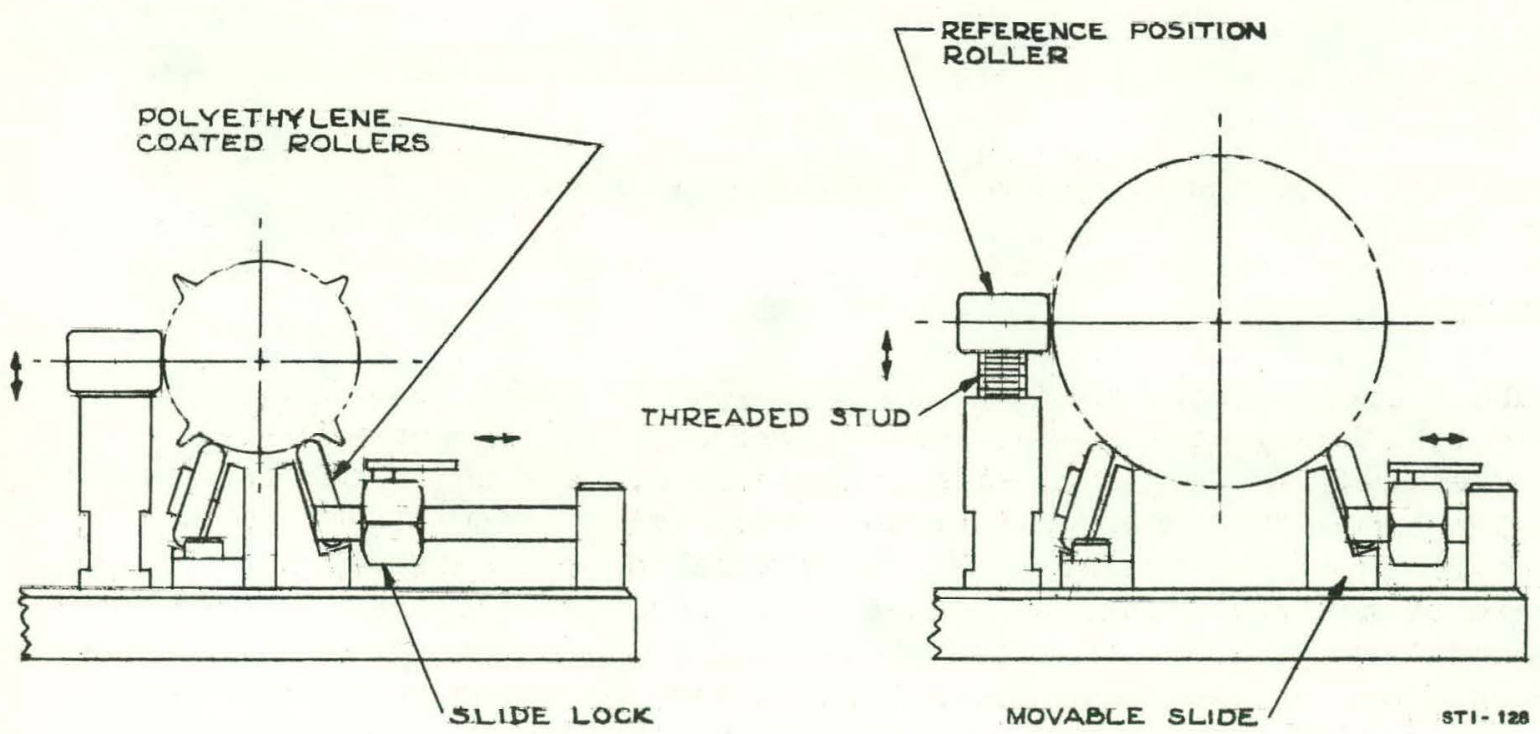

FIG. 2 MEASURING POSITIONS FOR ELEMENTS OF DIFFERENT DIAMETERS 
The reference position rollers contact the tube along its horizontal centerline to establish a straight reference line. The rollers have a $\frac{1}{2}$-inch face and do not need adjustment for most tube sizes. From the small diameter range to the large diameter range some adjustment of the roller is desirable to ensure contact with the tube centerline. This is accomplished by rotating the roller and its threaded post so as to move the roller up or down.

The dial indicator is a starrett Model No. 25-Cl graduated in units of 0.001 inch with a range of one inch. It is located midway between the two reference position rollers. Vertical adjustment of the indicator is required for each tube size so that the needle bearing follower (Figure l) will contact the tube along its horizontal centerline. The dial indicator has a threaded mounting post and is moved 0.060 inch up or down by each rotation of the indicator.

Two auxiliary roller support assemhlies are provided that arc idcntical to those on the gauge. Each assembly is mounted on a small base plate (Figure 3). The supports can be spaced at varying distances from the gauge depending upon the length of tube.

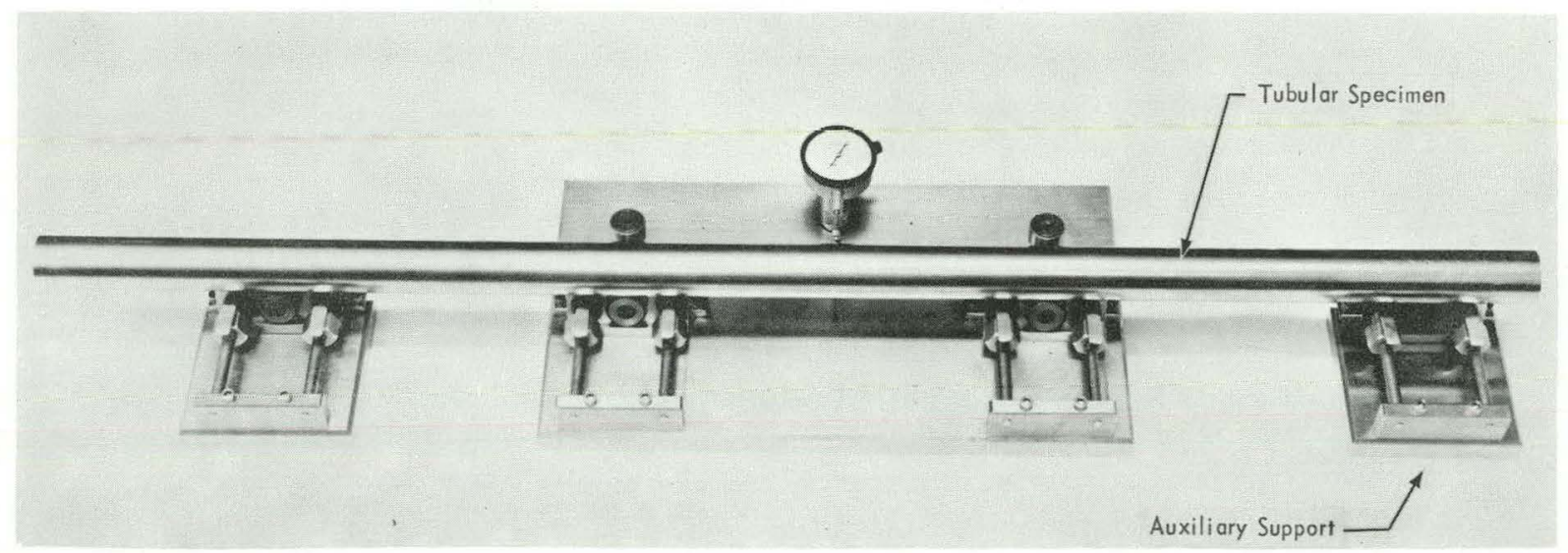

DPSTF - $1-5842$

FIG. 3 BOW GAUGE WITH TUBE IN MEASURING POSITION 


\section{OPERATION}

In operation a tube is placed on the canted rollers and the movable slides are adjusted and locked so that the tube makes contact with the support rollers and the reference position rollers. Vertical adjustments of the rollers and dial indicator are made if necessary. Next, the auxiliary supports are positioned and adjusted. The tube is moved through the gauge manually and bow measurements are read and recorded at one-foot intervals. Bow measurements of \pm 0.500 inch can be measured accurately within 0.001 inch on tube diameters from $1 \frac{1}{2}$ to $3 \frac{1}{2}$ inches. Tubes are then accepted or refected based upon established limits of, bow.

\section{OPERATING EXPERIENCE}

The gauge was installed in December 1961, and has been operated successfully since that time.

\section{ACKNOWLEDGEMENT}

The technique for measuring bow utilizing fixed reference points and a dial indicator was devised by $\mathrm{H}$. S. Hilborn of the Pile Materials Division, Savannah River Laboratory.

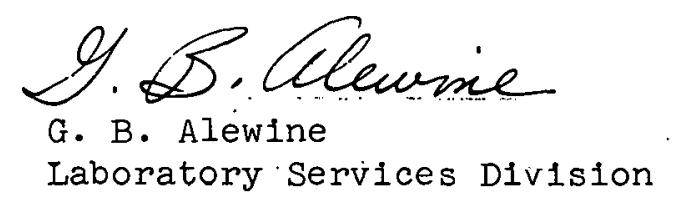

